九州大学学術情報リポジトリ

Kyushu University Institutional Repository

\title{
Michizane's Other Exile? Biographies of Sugawara no Michizane and the Praxis of Heian Sinitic Poetry
}

VAN DER SALM, NIELS

Leiden University, Skill Lecturer in Japanese

https://doi.org/10.5109/4377707

出版情報: Journal of Asian Humanities at Kyushu University. 6, pp.61-83, 2021-03. Kyushu University, School of Letters, Graduate School of Humanities, Faculty of Humanities バージョン:

権利関係 : 


\title{
Michizane's Other Exile? Biographies of Sugawara no Michizane and the Praxis of Heian Sinitic Poetry
}

\author{
NIELS VAN DER SALM
}

更妬他人道左遷

What's even more upsetting is how others speak of my "demotion."

Sugawara no Michizane, Kanke bunsō, fasc. 3

\section{Introduction}

ARLy Heian court scholar, poet, and official, Sugawara no Michizane 菅原道真 (845-903), in a poem preserved in his personal literary collection Kanke bunsō 菅家文草 (The Sugawara Literary Drafts), thus described being upset about rumors concerning his demotion - a common euphemism for “exile" (sasen 左遷, K187). ${ }^{1}$ As is well known, in 901 Michizane was accused of interference in the royal suc-

I would like to express my gratitude to Tina Dermois, Dario Minguzzi (La Sapienza University of Rome), and Bruce Winkelman (University of Chicago) for reading and discussing earlier drafts of this article. I also am indebted to the two anonymous readers whose critical remarks have greatly helped improve this article. Obviously, I alone am responsible for the shortcomings that still remain.

1 All source texts as well as their transcriptions are based on Kawaguchi Hisao's 川口久雄 NKBT edition. The numbering of Michizane's works follows this edition. Because his numbering deviates from the order of the manuscripts, I prefix his index numbers with a K. For the sake of consistency, below I also follow Kawaguchi's glosses, unless otherwise noted, except kana usage, which is adapted to modern spelling. Missing readings have been supplied as go-on 呉音 (the pronunciations of kanji that are considered to be the oldest stratum of Sinitic vocabulary in Japanese), in line with Kawaguchi. Subsequent scholars have frequently taken issue with Kawaguchi's idiosyncratic glosses (on which see NKBT 72, pp. 96-99); for a discussion, see Ōoka and Akiyama, "Taidan," pp. 6-8. Translations are my own, unless cession and sent into exile in Dazaifu 太宰府, where he died in ignominy two years later. This line, however, was written fifteen years earlier, in the first month of 886. In that year, Michizane was transferred from his post in the Bureau for Higher Learning (Daigakuryō 大学寮), the institution tasked with the education of the court's professional bureaucracy, to the island of Shikoku, where he was to serve a four-year term as Governor of Sanuki 讃岐 Province. ${ }^{2}$ What made Michizane describe this appointment in such strong terms? This question has occupied numerous scholars for the better part of a century and has produced a sizeable literature with interpretations ranging from Michizane's righteous indignation at political elimination to exaggerated lament over the most important promotion in his career. Curiously, one assumption remains unquestioned:

otherwise noted. I have also made use of Kawaguchi and Wakabayashi's concordance (Shiku sō-sakuin) throughout.

2 The Daigakuryō is alternatively known as the "State Academy" or the "University"; compare also Hérail's translation (Miyoshi no Kiyoyuki, p. 17) as "office des Études supérieures." Any translation is problematic for the associations it conjures up with modern research institutes; the Daigakuryō's primary function was to train men for bureaucratic service, not to further scholarship for its own sake. The caveat also applies to related terms, such as "professor of literature" and "scholars," which I retain for clarity's sake. 
shared between all these views is the implicit notion that if Michizane wrote poetry saying he was upset about the appointment, then Michizane must have, indeed, been upset about the appointment.

In the bleakest view, represented by historians Iyanaga Teizō 彌永貞三 (1915-1983) and Sakamoto Tarō 坂本太郎 (1901-1987), Michizane became the victim of Fujiwara power politics and academic strife. ${ }^{3}$ Critics have argued that the academic factions these scholars have identified cannot be reconstructed from surviving sources, while they also point out the amicable relations between Michizane and the most powerful Fujiwara of the day, Chancellor Fujiwara no Mototsune 藤原基経 (836-891). Robert Borgen is an early representative of this viewpoint in Anglophone scholarship, ${ }^{4}$ which Japanese historians such as Takenaka Yasuhiko 竹中康彦, Haruna Hiroaki 春名宏昭, and Kon Masahide 今正秀 later adopted independently, also calling attention to the fact that governorships were a common occupation for courtiers of middling rank. ${ }^{5}$ Niboshi Jun 二星潤 has recently demonstrated, though, that this career path had been a recent development for bureau graduates like Michizane, and therefore presented enough reason for him to feel frustrated, ${ }^{6}$ especially since the system had not yet developed the lucrative "custodial" governorships (zuryo 受領) familiar to readers of Heian kana classics. ${ }^{7}$ Nevertheless, other scholars - besides Borgen, Haruna, and Kon, also Endō Mitsumasa 遠藤光正— are probably right to suggest that the administrative experience gained during this period was an essential factor in Michizane's subsequent rise in the central bu-

3 lyanaga, "Ninna ninen no Naien"; Sakamoto, Michizane, pp. 66-68.

4 Borgen, Michizane, pp. 153-57.

5 Takenaka, "Sanuki no kami Michizane"; Haruna, "Nin Sanuki no kami"; Kon, Sekkan seiji.

6 Niboshi, "Bunjin no kokushi ninkan."

7 In particular, Sei Shōnagon, Makura no sōshi, section 22, ed. Watanabe, Shin Nihon koten bungaku taikei 25; or section 25 , ed. Ikeda, NKBT 19; and see also Hérail, "De la place et du rôle." During the period of Michizane's term, governors were under considerable institutional stress, being held personally accountable for tax deficits while they had few tools to ameliorate often dire financial situations (Batten, "Provincial Administration," pp. 119-22; Sasaki, Zuryō to chihō shakai, pp. 17-23). Over the two subsequent decades, this centralized administrative system would be largely abandoned in favor of a laissez-faire approach that "rewarded efficiency" and which would eventually lead to a situation where "nothing prevented [governors] from pocketing the balance" when revenue exceeded the tax burden (Batten, "Provincial Administration," p. 131). reaucracy. ${ }^{8}$ Yet despite this re-evaluation of Michizane's governorship, all these scholars-including even the economic historian Hirata Kōji 平田耿二, who sees in the assignment an actual promotion that was motivated by the court's trust in what he calls their "ace" (ēsu エース) administrator ${ }^{9}$ - maintain that for Michizane himself, the appointment was a matter of "misfortune" which he "hated" and found "extremely deplorable."

Comparisons with exile to Dazaifu, the search for inimical scholarly cliques, reconstructions of the career paths of graduates from the Bureau for Higher Learning - all these approaches seek to find an answer to the same underlying problem: What made Michizane's appointment such an unhappy one? But this problem raises another, more fundamental question: How do we know how Michizane actually experienced his assignment in the first place? Can we even assume this is knowable? The implicit answer to this question is that yes, we can, because he tells us so in his poetry: at the core of the discussion lie five poems that Michizane wrote between the announcement of his appointment and his departure for duty. Lines from these five poems and passages from the accompanying headnotes are quoted time and again to illustrate one core notion about Michizane's governorship: that it was an unwelcome appointment.

\section{最靯孤行海上沙}

What I lament most is that I will walk in solitude, along the sands by the sea.

$\mathrm{K} 183.8$

須里吟曰、明朝風景屬何人。一吟之後、命予高 詠。蒙命欲詠、心神迷亂、䌆發一聲、涙流嗚咽。 宴罷歸家、通夜不睡。默然而止如病忽塞。

After a brief pause, he [Chancellor Fujiwara no Mototsune] spoke to me, reciting: "Tomorrow's landscape - to whom shall it belong?" After reciting it once, he instructed me to chant it out loud. I took up the order and wanted to chant, but

8 Endō, "Michizane no seiji."

9 Hirata, Kesareta seijika, pp. 54-68.

10 Rabinovitch and Bradstock, Moonlight, p. 216; Sakamoto, Michizane, p. 65 (and see pp. 66, 70); and Fujiwara, Shijin no unmei, p. 111, respectively. See also Endō, "Sanshū jidai no Michizane," pp. 103-107; and Shirane, Traditional Japanese Literature, p. 132. 
my heart and mind were lost in confusion, and when I had barely uttered one sound, tears flowed and I broke into sobs.

After the banquet was over and I had returned home, all night I failed to get to sleep. Silent and unmoving, I felt like I was ill, and my chest felt tight.

K184, headnote

\section{讚州刺史自然悲}

As Governor of Sanuki Province, of course I am sad.

K185.1

\section{爲吏爲儒報國家}

Serving as a provincial official, serving as a learned man, we repay the sovereign [of this land].

K186.1

\section{更妬他人道左遷}

倩憶分憂非祖業

What's even more upsetting is how others speak of my "demotion."

I have carefully considered it, but "sharing the ruler's grief" was not the task of my forefathers.

$\mathrm{K} 187.2-3$

Extracted using the heuristic notion that expressions of personal experience provide us with autobiographical detail, these fragments convey a coherent and not unconvincing narrative that approximately runs as follows. The prospect of being on the road made Michizane sad, and the governorship that was waiting for him at the end of that journey was also a cause of griefso much so that when the chancellor quoted a poem that alluded to Michizane's departure, the latter broke down, sobbing uncontrollably at the banquet they both attended, and afterwards was unable to get any sleep. Michizane also tells us why he was so upset: although he declared himself prepared to serve as a provincial administrator just as he had as a scholar, he felt that the job did not suit him personally, given the scholarly positions his ancestors had also occupied. In fact, the appointment is counter to all expectations for a man like Michizane, and to his irritation, people whispered behind his back that he was being demoted and banished to another province.
Yet can we really assume that everything poets say about how they feel is an unmediated expression of personal sentiment? Old warnings about biographical fallacy notwithstanding, modern commentators are often inclined to see poetry as a vehicle for unmediated personal expression, an assumption that justifies its use as autobiographical, even documentary evidence for the poet's state of mind. ${ }^{11}$ But this interpretative strategy clashes with what scholarship over the past decades has taught us about the nature of Heian poetic practice. Instead of asking what Michizane felt as he wrote, I will argue that if we want to understand why Michizane wrote about himself, it is more fruitful to ask how, where, and with whom the poet engaged in poetic composition. Undercutting the autobiographical readings that privilege this type of emotional language, I claim that this approach enables us to understand poetic composition as more varied and complex than the heuristic notion that poets (ought to) write about their feelings, and that it does justice to not only the disiecta membra quoted above, but to the entire poems, left undisturbed in their original historical and textual context.

In the first section, I present an archaeology that deconstructs what I believe is a modern insistence on poetry's emotional language, which I trace back to the early years of the Japanese nation-state and the development of national literature's (kokubungaku 国文学) canon, in which Japanese poetry was redefined as a means of personal expression - a reading strategy that focuses on emotional language because it presumes that poetry immediately reflects the poet's inner world. In the second section, I review the recent literature on Heian poetic forms and practices - that is, external factors that influenced composition - to present an alternative interpretative framework for Heian poetry. The third section is devoted to an integral close reading of the five pre-Sanuki poems, to which the lines and passages presented above belong. My aim is to formulate an alternative reading of these poems, in which the personal, emotional charge of the poetry is initially ignored in favor of the external factors explored in section two. In the conclusion, I will bring these strands together to show how the reading strategy proposed in the second

11 Literary histories associate the term "biographical fallacy," which might be defined as "misreading the literary subject's works as though they were straight autobiography" (Winslow, "Glossary," p. 65), with the school of New Criticism. 
section and the analysis in the third provide a useful methodology and generate more insightful answers than the hackneyed view that Michizane's Sanuki poetry was only written to vent frustration. The ultimate aim of this study is therefore twofold. On the one hand, I hope to show how a more sophisticated argument can be made than "Michizane was dissatisfied with his appointment," one that is more attuned to the historical, rhetorical, and poetic contexts that motivated the use of emotional expression. On the other, this article is intended as a methodological contribution in which I question a positivist tendency to take source texts at face value, and suggest historicizing reading strategies that focus on the praxis of poetry, which help deepen our understanding of what literary texts attempted to say, and how they functioned at the time and place they were composed and performed.

\section{Fragmentation, Modernity, and Autobiography}

In the preface to their most recent shi 詩 anthology, No Moonlight in My Cup, Judith Rabinovitch and Timothy Bradstock explain that while they strove to compile a representative selection of poetry,

[i]n selecting verse for this work, particular attention has been paid to informal and private poetry, comparatively little of which has ever been translated. These poems tend to have more lyrical and human interest than the formal court kanshi, offering significant insights into the personal lives and aesthetic sensibilities of courtiers. ${ }^{12}$

Their claim to the contrary notwithstanding, Rabinovitch and Bradstock are in good company when it comes to their principles of selection. As Kristopher Reeves argues in his dissertation on ninth-century Heian poetry, for a previous generation of translators, the distinction between "conventionalized" and "highly personal poetry" played an important role in establishing what was worth anthologising. ${ }^{13}$ Writing about Burton Watson's (1925-2017) anthology of Sino-Japanese verse, Reeves argues that his selection of Michizane's

12 Rabinovitch and Bradstock, Moonlight, p. ix.

13 Reeves, "Poetry, Patronage, and Politics," p. 12, referring to Watson, Japanese Literature in Chinese, pp. 12-13. shi is clearly skewed towards lyrical poems that could be construed as moments of personal self-expression and cris de coeur.

Watson endeavors to present to his English-speaking audience those scattered poetic pearls [...]. Only serious and highly personal poems are to be included. Michizane's biographical poems about historical figures [the subject Reeves is discussing] do not contain that same sort of interiority, and therefore, I suspect, have been left aside as unworthy of inclusion in our English selections. We as modern readers [...] must handle translations with care, for they are bound to present us with a very prejudiced, albeit appealing - because of their alignment with modern attitudes about poetry - picture of Heian Sinitic poetry. To be sure, a number of Michizane's poems, [...] do smack of something we might recognize as deeply emotional. Even so, as his biographical poems have shown this was certainly not always the case. ${ }^{14}$

In this section, I explore how these "modern attitudes about poetry" have helped to construct and maintain the reading strategies that engendered this fragmentation into anthologies, attitudes that also shape the selective operation through which Michizane's Sanuki poems have been read as autobiographical expressions of personal experience. That is not to say that I intend to deny the presence of something "deeply emotional." After all, premodern East Asian critical language does connect emotion to poetic expression, such as in commentaries on the ancient continental Odes (Shijing 詩経), in the preface to the Kokin wakash $\bar{u}$ 古今和歌集 (Collection of Poems Ancient and Modern, after 905), and most poignantly, in the letter Michizane wrote to accompany the presentation of his collection Kanke bunsō to the throne in 9oo, where he states about his time in Sanuki, "[ $t]$ he emotions that stem from experiencing the world around me: I cannot fathom their abundance; the pleasures of a poet: only by guessing can we measure them" (觸物之感、不覺滋 多。詩人之興、推而可量). ${ }^{15}$ Nevertheless, I do wish to direct attention away from interiority and the language

\footnotetext{
14 Reeves, "Poetry, Patronage, and Politics," pp. 697-98. Emphasis mine.

15 K674. On the Odes and Kokin wakashū, see Fujiwara, Michizane to Heian-chō kanbungaku, pp. 128-30.
} 
of emotion, which has come to occupy an excessively prominent place in the interpretation of Michizane's supposedly "personal" poetry. An extreme example may be found in the Michizane biography authored by literary scholar Fujiwara Katsumi 藤原克己, who in his introduction describes Michizane's poethood in the following terms.

But he [Michizane] possesses a certain pure ethic, born out of a poetic disposition (shishin 詩心) that is all but useless in politics - a delicate sensibility that unfailingly picks up the shifting of the seasons, quicker than others, or a kind spirit that loves people, plants, flowers, birds, the stirring of the wind. One of the points I want to stress in this book is this point: that that is the ethic of the poet. ${ }^{16}$

Fujiwara's construction of Michizane's poetry out of the poet's subjective experience is clearly grounded in a romanticist conception of poetic expression. ${ }^{17}$ As a literary current that values the (supposedly) immediate expression of a poet's innermost feelings, this critical perspective justifies the focus on a poet's language of emotion. While Fujiwara consciously conceptualizes his approach, however, in some senses his work constitutes only the rationalization of the praxis of his predecessors. These scholars include not only biographers-Sakamoto Tarō in Japanese, and Robert Borgen in English, whose biographies (1962 and 1986, respectively) are littered with autobiographical detail gleaned from Kanke bunso ${ }^{18}$ - but also the great postwar scholar of Sino-Japanese literature and doyen of Michizane textual scholarship, Kawaguchi Hisao 川 口久雄 (1910-1993), whose NKBT edition enshrined Michizane's poetry as an authentic representation of the poet's inner feelings when he argued the following.

Is it not true that in works of literature alone, when a text close to the autograph has been handed down to us, as long as we carry out proper interpretation, we should be able to hear the sighs,

16 Fujiwara, Shijin no unmei, p. 13

17 Ibid., p. 14, and see his article, "Michizane: Le poète."

18 This approach is also echoed in other biographies, such as those by Gerlini, Poesie scelte; Higashi, Kujira; and Tokoro, Michizane no jitsuzō. groans, the very voice of the author himself just as they once had been? ${ }^{19}$

For Kawaguchi, who described Michizane's writings as "the collected works of an individual," the value of his compositions-the poetry in particular-lay in the direct access these works could grant to their author's inner world. ${ }^{20}$ Kawaguchi's statement should be read, however, as more than a naïve understanding of Michizane's poetic language, for this rhetoric reflects the trend (shared with many other postwar scholars of Sino-Japanese literature) to "reincorporat $[\mathrm{e}]$... the literary Sinitic corpus into the discursive field of 'Japanese Literature" "from which it had been excluded. ${ }^{21} \mathrm{As}$ Robert Tuck has explained in lucid detail, despite the central place Michizane occupied as paragon of loyalty in the imagination of modern Japanese national identity, the Michizane mythos failed to secure Michizane any significant readership. ${ }^{22}$ Although hailed as the quintessence of early Heian poetry, Michizane's works achieved their status not because of careful literary analysis but for their ideological potential: ${ }^{23}$ in his poetry, Michizane was thought to have subjugated Chinese form to express authentically and sincerely Japanese content, ${ }^{24}$ "defending the nation from foreign influence" in the process. ${ }^{25}$ In postwar discourse, this markedly modern narrative, which sought to cope with an anxiety over national identity, was stripped of its most overtly jingoistic paraphernalia, but left in place a rhetoric of poetic authenticity available for Kawaguchi to suggest that Michizane's works ensured, if not access to an untainted national identity, then echoes of an authentic individual voice.

More than an analysis of Michizane's oeuvre, therefore, postwar narratives of Michizane's works (such as

19 Kawaguchi, NKBT 72, p. 24.

20 lbid., p. 24. Poetry's privileged position is evident from the casualness with which Kawaguchi split up the first half (poetry) and second half (prose) of Kanke bunsō so as to insert the later Kanke kōshū (Michizane's one-fascicle collection of Dazaifu poetry) between them (p. 95), and the fact that he paid hardly any editorial attention to the prose (pp. 527-634 of a 739-page edition).

21 Steininger, Chinese Literary Forms, p. 5, n. 10.

22 Tuck, "Poets, Paragons, and Literary Politics," pp. 46, 52-54, 70-75.

23 Ibid., pp. 55-56, 59, 65, 87, 89; see p. 74 for a counter-example.

24 Ibid., pp. 47, 85-90, 94

25 Ibid., pp. 46-47. Even today, Michizane's perceived antiChinese-ness is a keystone in conservative narratives about Michizane, such as the assumption-ridden "explanation" of Michizane's exile in an essay by history textbook reformist ljiri Kazuo 井尻千男 (1938-2015), "Michizane higeki no shinsō." 
those of Kawaguchi and Fujiwara) can be read as rhetorical, because they respond to, and seek to reorient, the language of authenticity and sincerity their modern forerunners had used to dismiss Michizane's compositions. This dismissal is tightly entwined with the fundamental reorientation of the literary canon as a part of the development of kokubungaku, which scholars over the past two decades have insistently probed for its connections to the emergence of the modern Japanese nation-state. ${ }^{26}$ For example, the status of prose rose greatly in comparison with traditional genre hierarchies, so that Michizane, known primarily for his poetry, was left behind in the new canon; ${ }^{27}$ and Heian literature came to be perceived as a site of femininity, which meant that Michizane could not be conceived of as a representative author, either in terms of his own gender or the forms of Sinitic that he employed, which were predominantly the domain of male writers and had long been gendered as a masculine enterprise. ${ }^{28}$ Most crucial, however, was the redefinition of the canon in terms of a-modern, Japanese-national language and the accompanying exclusion of all texts perceived as "un-Japanese." ${ }^{29}$ This extended to the shi poem, which was written in the Sinitic literary language and was therefore reconceptualized as something inherently and irredeemably Chinese, despite its nearly two millennia of use as a shared medium of textual expression throughout East Asia. ${ }^{30}$ Not coincidentally did the shi come to be increasingly referred to by the (still-current) ethnically marked term kanshi 漢詩, or "Han poem." ${ }^{11}$ This was more than an issue of language: a failure to use one's native tongue was explained as a failure to convey thoughts, feelings, and sentiments that were truly Japanese-they would be "stylized and mediated," its language "ceremonious, mannered,

26 For premodern forerunners to the modern canon, see Brownstein, "Kokugaku to Kokubungaku"; Kurozumi, "Kangaku," pp. 214-16; Yoda, Gender and National Literature, pp. 45-50.

27 Shirane, "Canon Formation," pp. 4-9.

28 See for this view especially Yoda, Gender and National Literature.

29 Discussed in, for example, Kurozumi, "Kangaku"; LaMarre, Uncovering Heian Japan; Sakaki, Obsessions; Shirane, "Curriculum"; and Yoda, Gender and National Literature.

30 For the Japanese archipelago, see for example Rabinovitch and Bradstock, Moonlight, p. 121; Sakaki, Obsessions, chapters 3 and 4 (pp. 103-76); and Tuck, Idly Scribbling Rhymers, chapters 1 and 2 (pp. 1-81).

31 Rabinovitch and Bradstock, Moonlight, p. 4. There is no consensus on the use of the term kanshi and its translations: Kornicki, "A note on Sino-Japanese," and Wixted, "Kanbun." Here I retain the name (kan)shi in its transcribed form. inauthentic." ${ }^{2}$ To claim that Michizane's literary writings are a window into his soul, as Kawaguchi claims, is therefore more than staking a claim about a framework for literary analysis: it is also, maybe even primarily, an attempt at repurposing the language of authenticity to bring Michizane back into the fold of Japanese literature-quite literally, as an edition in Iwanami's leading kokubungaku series of text editions.

Postwar scholarship on Michizane has thus managed to complicate the glotto-centric conception of the modern canon. An assumption that was left untouched, however, was that of the relationship between literature, poetry in particular, and the author's inner world. Literary critics and historical biographers alike avow an unwavering faith in the reliability of Michizane's poetry as a medium to convey unmediated thoughts and feelings. I would argue that this approach to poetry, too, relies on a historically specific conception of literature, one that in many ways is particular to the modern period. On the one hand, it echoes Euro-American romanticist notions of poetry as an expression of the lyric genius, which were current when kokubungaku began to formulate itself. More specifically, the problem of human emotion (and how to write about it) appears to have been a very specific concern of modern Japanese authors, as Daniel Poch has recently argued in the case of Natsume Sōseki 夏目漱石 (1867-1916). ${ }^{33}$ It seems likely, therefore, that the preoccupation with sincerity in prewar Michizane narratives that Tuck explored, as well as the conflation of author and lyric "I" in the current interpretations of Michizane's literature, can trace their lineages to the modern predilection for lyric poetry that Reeves warns us about in the passage quoted at the beginning of this section.

This suggestion should alert us to the possibility that privileging expressions of interiority may not be a useful reading strategy when attempting to reconstruct how Michizane's shi were thought to work when they were first composed. Although shi frequently represent a first-person perspective, and the correlation between author and "I" is often strong, this does not mean that this first-person narrator can be unquestionably assumed to represent an "autobiographical self." This term is used by sinologist and comparitivist Eugene Eoyang in contradistinction to the "generic self," when

32 Webb, "In Good Order," p. 39 33 Poch, "Measuring Feeling." 
he compares the rhetoric of classical Chinese poetry, where poets tended to write about their lives in alignment with literary conventions (in particular, expressions of the self that were bound by genre rather than the poet's own subjective experiences), to the modern tendency to interpret personal poetry as expressions of an autobiographical, self-reflexive subject. ${ }^{34}$ Modern readers, in other words, are at risk of succumbing to an "excessive lyricism" 35 that privileges the individual subject as the primary locus of signification, and which opens up poetry as a medium for the representation of private experience and authentic expression. ${ }^{36}$ So what other options do we have besides a lyrical reading of Heian shi? What happens if we decenter the fragments of emotional language that are highlighted by such a strategy? In the next section, I will discuss how recent scholarship has reconstructed Heian poetic production as a social, performative practice, which suggests how we should pay attention to the contexts in which emotional language functioned-both textual, in the sense of the poetics of entire poems, and social, in the sense of the setting and audience that witnessed its composition. This enables the formulation of an interpretative model for ninth-century Heian shi that, as I will show in a detailed analysis of Michizane's five pre-Sanuki poems in section three, I believe can help us achieve a richer understanding of the function and meaning of Heian poetry.

\section{A Short Poetics of Early Heian Shi}

The existence of complicated networks of courtly duties, family obligations, and personal relationships ... meant that individuals inevitably participated in, and were subject to the norms of, more than one collectivity. [...] Context is paramount. It galvanizes individuals, if in some cases just for

34 Eoyang, "Generic Self," pp. 245-46. A good case in point is the negotiation of patronage relationships and Michizane's leisurely poetry as studied by Reeves, "Poetry, Patronage, and Politics," pp. 157-269 and 661-98, respectively. Although seemingly lyrical, Reeves suggests that this poetry's meditative mood is in large part deliberately chosen, adopted by the poet only during times of otium, when poetry could be employed for the expression of solitude.

35 Takenaka, "Sanuki no kami Michizane," p. 268 à propos interpretations of Michizane's works.

36 See for example Yoda, Gender and National Literature, pp. 8-13; Smits, "Sorting out Songs," pp. 1-2. the moment. It changes how poetry is written, and texts interpreted. Our methodology must adequately capture those distinctions.

Jason Webb, "In Good Order," pp. 12-13.

Instead of relying on the experiencing subject, recent scholarship has sought to explain Heian poetic formboth waka 和歌 (“harmonizing poem," or “Japanese song") and shi-in terms of its social context and poetry's performativity. Gustav Heldt in The Pursuit of Harmony: Poetry and Power in Early Heian Japan has put forward the argument that poetry and its social (and political) effect rested on proper adherence to specific aesthetic norms. ${ }^{37}$ Brian Steininger, in his recent Chinese Literary Forms in Heian Japan: Poetics and Practice, has explored in more detail what these norms were in the case of mid-Heian textual culture, and indicated how adopting established poetic practice (and not personal innovation per se) was key for producing passable occasional verse.$^{38}$ Kristopher Reeves has recently shown that skilful navigation of these expectations of genre and audience already played an important role in the choices made by early Heian shi poets. ${ }^{39}$

In the analysis in section three, I will show that negotiating relationships with an audience is an important aspect of the banquet poems Michizane composed before his departure. This is not only true in the case of court banquets, but also applies to more informal gatherings in Michizane's own honor, such as one that was organized at Chancellor Mototsune's poetry salon, the "Eastern Sidegate" (Tōkō 東閤), where Michizane had been a frequent visitor to participate in sessions of joint poetry competition. ${ }^{40}$ Such events illustrate a second important characteristic of poetry composition at the Nara and Heian courts, namely the importance of poetry as a "social act." ${ }^{41}$ Poetic composition typically meant poetry recitation or poetry exchange, and the setting and the audience determined the parameters within which these acts were performed, including factors such as genre, linguistic register, and topic. Banquet poetry represents only the most easily recognizable setting for such joint composition, for less

\footnotetext{
37 Heldt, Pursuit of Harmony, introduction and chapter 1 (pp. 1-8o)

38 Steininger, Chinese Literary Forms, chapter 3 (pp. 79-124).

39 Reeves, "Poetry, Patronage, and Politics," chapters 1 and 2 (pp. 45-269).

40 Kawaguchi, NKBT 72, p. 681; see for example K140, K146.

41 Smits, "Way of the Literati," pp. 115-16.
} 
public poetry was equally used to affirm social relationships and to serve as a means of communication; as Rabinovitch and Bradstock have it, poetry "served an important interpersonal communicative function, becoming a vehicle for offering praise, sympathy, and words of gratitude, as well as for deflecting criticism and hinting at hoped-for favor." ${ }^{2}$ While poetry with such obvious perlocutionary force as the banquet poem was evidently rhetorical in nature, in fact even the intimacy of two poets exchanging what one might cautiously term "personal" poetry is no guarantee for reliable autobiographical detail either, as familiarity enabled poets to employ wit and rhetorical devices such as irony and hyperbole without running the risk of becoming unintelligible or obscure. ${ }^{43}$

In order for occasional poetry to work-as a medium of expressing, codifying, affirming, negotiating, and undermining hierarchies and social ties - it was necessary for poets to acknowledge, if not play with, certain guiding principles. Composing shi is often described as a challenge or a chore because of the large number of rules that had to be followed, including meter, tonal patterning, and rhyme, while a poem's structure followed a set pattern and its contents were often expected to be highly allusive as well. While writing shi was probably no sinecure, however, these rules also served as guideposts for participating poets and (in contexts where poetry was subject to evaluation) for comparison as well. Steininger writes, à propos the kudaishi 句題詩 (“topic line poetry”), that “[ $\mathrm{t}]$ he standardization of poetry both lowered potential barriers to participation in group composition and made direct comparison (and therefore competition) among participants unavoidable," 44 but I would argue that is true for the composition of occasional poetry in general. A knowledge of which rhymes to use, what language and topics are appropriate, and where in a poem to place each element both unburdens poets by reducing the number of choices they have to make as they extemporize, and coordinates their efforts into a coherent whole. ${ }^{45}$ It is tempting to draw a parallel between Heian poets' experience of social versification on the one hand, and on the other, that of eighteenth-century

\footnotetext{
42 Rabinovitch and Bradstock, Moonlight, p. 3.

43 Eoyang, "Generic Self," p. 246.

44 Steininger, Chinese Literary Forms, p. 109.

45 See Heldt, Pursuit of Harmony, pp. 17, 48; Webb, "In Good Order," p. 101
}

Viennese nobles who could waltz to quite predictable accompaniment, or a handful of mildly skilled pop musicians who can improvise a twelve-bar blues jam during their first session together.

Several of the guidelines provided by this framework of shi composition are important for understanding the five poems I will analyze, so I will briefly sketch each of them in the remainder of this section. Before composition begins, poets were often provided with a topic (dai 題), either decided upon by the person presiding over the gathering, or chosen by drawing slips upon which topics were written (tandai 探題). ${ }^{46}$ The rhyme word(s) that had to be used could likewise be decided upon in advance, or established by lot (tan' in 探韻). ${ }^{47}$ In this way, not only were poets liberated from having to rely on their "inspiration," it was also possible to steer compositions and thus ensure that they would be appropriate to the occasion - in fact, Reeves suggests that even the act of randomly drawing rhymes may sometimes have been carefully prepared instead of being left to assignation by lot. ${ }^{48}$

With this, the poet set to work crafting a poem guided by a number of compositional principles, chief among them the function of each line within the poem, and the expectations and requirements of the genre that was being composed. In a quatrain, each of the four lines served a specific purpose: the opening line (hokku 発句) was used to introduce the setting or topic of composition, the two middle lines (kyōku 胸句 and $y \bar{o} k u$ 腰句) developed the topic through variation on the original theme and allusion to classical examples, while the final line was reserved for the expression of personal sentiment (rakku 落句). ${ }^{49}$ This framework is of course very general, and variation exists - in octaves, the division of verses was two-four-two, and in less allusive poetry, a clear break could often be found between the second and third lines ${ }^{50}$ - but generally speaking the place of a line within the poem carried a certain semantic weight.

\footnotetext{
46 Rabinovitch and Bradstock, Moonlight, p. 103

47 Ibid., p. 106

48 Reeves, "Poetry, Patronage, and Politics," p. 637.

49 Ogawa, Tōshi gaisetsu, pp. 163-64; Rabinovitch and Bradstock, Moonlight, pp. 95-97. For the terminology, which could be rendered into English as the "opening, breast, waist, and completing" couplets, see also Sakumon daitai 作文大体 4, translated in Steininger, Chinese Literary Forms, p. 234.

50 For example, the ten 転 of a ki-shō-ten-ketsu 起承転結 structure; see also Ogawa, Tōshi gaisetsu, pp. 163-64.
} 
The choice of genre, on the other hand - which itself was influenced by the setting where and audience for whom the poet composed ${ }^{51}$-helped poets to choose between a plethora of expressive possibilities at their disposal to fulfil the aim of each line: for instance, the choice of tropes, the language register, or the implied relationship between poet and audience..$^{52}$ To illustrate, formal banquet poetry (such as K183), which was composed at official palace ceremonies, would open with a description of (an aspect of) the ceremony itself, develop this statement through variation and lofty allusion to loci classici and other exempla, and close with a personal observation by the poet (jukkai 述懐). ${ }^{53}$ The language employed was formal and solemn, and the poet thematized the grandeur of the occasion and its host (for example, the sovereign), implying gratitude in an asymmetrical relationship between host and guest. ${ }^{54}$ Farewell poetry, however (to which $\mathrm{K} 185-\mathrm{K} 187$ belong, although properly speaking the term usually seems to be reserved for poems presented to the departing traveler) while adhering to the same basic pattern, uses less ornate language and implies a relationship between equals, or at least a sense of friendship/intimacy. 55 The themes that are developed are less allusive in nature, refraining for instance from direct reference to historic examples. Nevertheless, they do conform to certain thematic patterns of their own. William Matsuda's article on Kūkai's 空海 (774-835) “epistle-poems" to provincial governors draws out how these works displayed a tendency to represent the provincial periphery (especially in the northeast) as uncivilized frontier regions, while the life of the governor was expressed in terms of its many hardships. ${ }^{56}$ These hardships were a theme familiar from many continental works, including examples such as Qu Yuan's 屈原 (343-278 BCE) Li sao

51 For the role of setting in the production of poetry, see also Smits, "Way of the Literati," pp. 115-17.

52 For a discussion of generic choices, see Reeves, "Poetry, Patronage, and Politics," chapters 4-5 (pp. 477-735), especially pp. 573, 590-91.

53 Rabinovitch and Bradstock, Moonlight, p. 96. Brian Steininger's description (Chinese Literary Forms, pp. 114-15) of jukkai's function in mid-Heian shi as an expression of "[a]n authorial stance of aggrieved misfortune" may also apply to certain earlier examples, such as Ryōun shinshū 凌雲新集 34; Bunka shūreishū 文華秀麗集 67 (Rabinovitch and Bradstock, Moonlight, pp. 148-49 and pp. 168-69); as well as K183.

54 Rabinovitch and Bradstock, Moonlight, pp. 37-38.

55 Reeves, "Poetry, Patronage, and Politics," p. 573.

56 Matsuda, "Poets on the Periphery."
離騒, in whose portrayal of exile Eugene Eoyang traces the "generic self" of the underappreciated scholarofficial; 57 and the near-contemporaneous writings of Bai Juyi 白居易 (772-846), which may have provided an important model for how Michizane would describe his own life as court official..$^{58}$ At the Heian court, too, where exile was effectively the most severe punishment that could be imposed on a courtier, the periphery tout court carried strong associations with exile in particular. ${ }^{59}$ Significantly, historian Niboshi Jun has recently argued that the bureau graduates of Michizane's day, suffering from the bureau's diminishing prestige, saw themselves assigned to the provinces more frequently than their predecessors several decades before. He stresses how not only Michizane, but also scholar-officials such as Fujiwara no Sukeyo 藤原佐世 (?-897) and Miyoshi no Kiyoyuki 三善清行 (847-918), all used the language of exile to describe provincial administration, which already begins to suggest how "demotion" may have been a figure of speech, rather than the historical reality readers of Michizane's Sanuki poetry have constructed from it. ${ }^{60}$

The final outcome of the act of composition is thus much more than a reflection of the poet's personal experience, determined as it is by numerous other factors such as the social nature of poetry, the expectations of audience and genre, and the appropriate use of language, allusion, and motifs. For these reasons Takenaka Yasuhiko, as one of very few scholars to discuss the methodological problems involved in using Michizane's own works for biography, warns us not to overestimate the "reliability" (shinpyōsei 信憑性) of his poetry as historical fact, stressing its "grandiloquence" (kodai na hyōgen 誇大な表現) as an obstruction instead. ${ }^{61}$ In the following section I return to the five poems Michizane wrote between the moment his appointment was announced and his departure for Sanuki and analyze them from the perspective that interpretations of Heian shi should account for the poetic practices surveyed in this section. I will argue that these poems were not general laments about the fate of a poet-turned-governor, but that each had a specific purpose and catered to a

\footnotetext{
57 Eoyang, "Generic Self," pp. 245-46.

58 Takenaka, "Sanuki no kami Michizane," pp. 272, 281.

59 Stockdale, Imagining Exile, introduction and chapter 5 (pp. 1-16, 85-113).

60 Niboshi, "Bunjin no kokushi ninkan."

61 Takenaka, "Sanuki no kami Michizane," pp. 267-68.
} 
specific setting and audience, which interferes with the autobiographical reading typically applied to them.

\section{Poems in Their Place}

We know that the five poems under discussion were written right before departure because of a headnote in Kanke bunsō. These headnotes are a product of Michizane's own act of compilation: in 900 he presented the collected works of three generations of the Sugawara house to the throne, with his own twelve-fascicle literary collection as its culmination. The third and fourth fascicles, which contain the poetry from the Sanuki years, were first compiled around 894 or 895 to be presented to Prince Atsugimi 敦仁, heir apparent, and the definitive twelve-fascicle edition was presented to him after he had succeeded to the throne as Daigo tenno 醍醐天皇 (885-930, r. 897-930). ${ }^{62}$ Since many of the poems had been composed before Atsugimi/Daigo became politically active at court, these headnotes can be understood as reading guides for royal eyes, and as such they steer our interpretation of the Sanuki poems. More generally, the coordination of these poems into a single text implies other reading strategies as well. The scroll format, in particular, cannot be easily leafed through and thus forces the reader to at least take note of, for instance, the presence of the first four poems before reaching the fifth. It thus suggests that these poems in this context were expected to be read together. ${ }^{63}$ By way of experiment, however, in this section I will ignore these poems' intratextual coherence, and following from the preceding outline, focus instead on what we may reconstruct of their social and rhetorical contexts when they were first composed.

The first poem (K183), with which fascicle three opens, accompanies a poem Michizane composed at the Naien 内宴, or “Residential Palace Banquet." This banquet, which was held at the sovereign's quarters around the twentieth of the first month, probably func-

62 Taniguchi, Shi to gakumon, pp. 83-86. Taniguchi suggests (p. 81) that the first five poems may not have been part of the original Sanuki collection, as they do not technically belong to the poetry written in Sanuki. For the use of tennō 天皇, see Piggott, Kingship, pp. 8-9.

63 Sumiyoshi, "Gozanban no sōtei," p. 472, suggests that the codex format did not begin to appear in the archipelago until the late Heian. I would like to express my gratitude to Sasaki Takahiro 佐々木孝浩 of Keio University, to whom I owe this reference. tioned as the conclusion to the various first month celebrations and involved dance, musical entertainment, and poetry extemporized by the attendant court poets. ${ }^{64}$ Michizane's oeuvre suggests that together with the annual Double Ninth Festival (Chōyo 重陽) banquet, which was held on the ninth day of the ninth month, these banquets constituted his most important public venue to display poetic skill. In Naien poetry, this skill was put to use in describing the banquet's refinement and beauty, especially of the dances, and praising the sovereign's beneficence, through which the event had been made possible. ${ }^{65}$ The poem that Michizane wrote for the occasion, and the headnote that explains this, run as follows.

\section{早春内宴、聽宮妓奏柳花怨曲、應製。〈自此以後、 讚州刺史之作。向後五首、未出京城之作。〉}

\section{宮妓誰非舊李家 \\ 就中脂粉惣恩華 \\ 應緣奏曲吹姜竹 \\ 豈取含情怨柳花 ${ }^{66}$ \\ 舞破雖同飄綠架 \\ 歡酣不覺落銀釷 \\ 餘音縱在微臣聽 \\ 最歎孤行海上沙}

In early spring at the Naien banquet, as we were listening to the palace entertainer girls performing the song Ryūkaen [Resentment of the Willow Blossoms], I composed a poem as per royal command. (Hereafter follow compositions by the governor of

64 Hatooka, Kyūtei shijin, pp. 50-51. See also Rabinovitch and Bradstock, Moonlight, pp. 34-35.

65 Hatooka, Kyūtei shijin, pp. 62-64.

66 Murata, "Michizane shishō," p. 34, remarks that the expression is very rare, and has to resort to an ad hoc interpretation of toru 取る as "to take [a particular action]." While there is no direct textual evidence in the variae lectiones to support emendation (see for example the three-volume Hizen Shimabara Matsudaira Bunko 肥前島原松平文庫 manuscript of Kanke bunsō, date uncertain, or the six-volume print edition first published in Genroku 元禄 13 [1700]), parallels in Michizane's oeuvre suggest 豈敢 as an alternative for 豈取 (besides K219.32, where it is also used in conjunction with the phrase 應緣, also K226.8; K238.1; K240.8; K446.1). Calligraphically, the 取 and 敢 characters can be rendered similarly (see Kodama, Kuzushiji yōrei jiten, pp. 136, 437), and a twelve-fascicle scroll manuscript held at the Dōmyōji Tenmangū 道明寺天満宮 suggests a copyist's hesitation over the expression, as it shows one additional brush stroke above the ear-radical on the 取 character. Thus emendated the line could be read, "[So] how could I dare harbor feelings and resent the willow flowers?" 
Sanuki. The following five pieces are compositions from when I had not yet left the capital.)

Who of these palace dancers is not of the House of Li of old?

Their red and white make-up in particular, all are flowers bestowed by royal grace.

It must be because they perform this song that they play the Qiang flutes,

So why should I choose to nurse these feelings and resent the willow flowers?

The dance quickens, and they all flutter their green branches, but

Their pleasure climaxes, and they do not notice how they drop a silver hairpin.

While the echo remains in your lowly servant's ears,

What I lament most is that I will walk in solitude, along the sands by the sea. ${ }^{67}$

Reading the poem in full shows that the lines that describe Michizane's own state of mind (the lines to which biographers turn ${ }^{68}$ form the jukkai couplet of this banquet poem: no sudden cry of grief, they are instead an expression of personal sentiment that is required by the poetics of banquet poetry. In fact, as Murata Masahiro 村田正博 has shown in a detailed analysis of the full poem, its jukkai is tightly interconnected with the rest of the composition: ${ }^{69}$ far from spontaneous, it is a carefully controlled conclusion to the six lines that describe the banquet dance. In this analysis, Michizane's reference to his new appointment is not the ultimate aim of the poem; instead, his imminent departure plays a support role because of the double perspective on the Ryūkaen performance it grants Michizane, a perspective that informs the conceit of the poem.

Murata reconstructs how at the Heian court, $R y \bar{u}$ kaen was primarily performed for its sophistication and allure, as illustrated by the eventual replacement of the ominous expression “resentment” (en 怨) in the piece's name by the more auspicious “garden" (en 苑). ${ }^{70}$ This is reflected in Michizane's description of Ryūkaen: he

67 For other translations, see Borgen, Michizane, p. 150, and Murata, "Michizane shishō," pp. 33-35.

68 lyanaga, "Ninna ninen no Naien," p. 92; Hatooka, Kyūtei shijin, p. 65.

69 Murata, "Michizane shishō," pp. 36, 42-43.

70 Ibid., p. 38. compares the danseuses to the famously skilled dancer Li furen 李婦人 (“Lady Li," second century BCE) and praises their exquisite, royally-bestowed make-up, while the girls themselves are so engrossed in their performance that they forget everything else. ${ }^{71}$ Nevertheless, Michizane himself is aware of the classical implication of the title: "resenting the willow blossoms" is associated with the sorrow of leaving the capital in early spring, when the willow was in full bloom. ${ }^{72}$ That is why in 1l. 3-4 he detects a conflict between the refined flute melody and the conventional meaning of "resenting the willow blossoms": he knows that the "Qiang" flute refers to a nomadic group on the fringes of the sinosphere, but suggests instead that the instrument was chosen as accompaniment to a splendid performance, not because of the association with departure to foreign lands. ${ }^{73}$ The antithesis (iedomo 雖) in 11. 5-6 also hinges on this double vision: from the poet's classical point of view, the performance's climax should express deep grief, but for the girls absorbed in their danceand for the spectators at court - it is abstracted to a moment of intense pleasure (yorokobi wa takenawa ni shite 歡酣). ${ }^{74}$ As a conclusion to these observations, the final couplet thus becomes the interpretive key to the poem as a whole: here Michizane explains what had attuned him to alternative associations, and provides a different reading of the banquet performance, which allows him to both showcase his learning and at the same time imply that the performance is perfectly in line with cultural precedent.

In hindsight, the explicit reference to Michizane's own departure activates a third possible interpretation of the poem: as an allusion to the story of Wang Zhaojun 王昭君 (first century BCE). Wang Zhaojun was one of the most attractive concubines of emperor Yuan of Han 漢元帝 (75-33 BCE), but her beauty remained unnoticed and was only recognized by the emperor after he had unwittingly promised her as tribute to one of the leaders of a border tribe..$^{75} \mathrm{~A}$ number of elements in the poem point in her direction: Wang Zhaojun is

71 Ibid., pp. 33-35. Kawaguchi's suggestion (NKBT 72, p. 247) that "the House of $\mathrm{Li}^{\prime}$ refers generally to the Tang dynasty is less convincing.

72 Murata, "Michizane shishō," pp. 38-39. See also K364.5-6.

73 Ibid., p. 34 .

74 Ibid., pp. 39-40.

75 Numerous versions of the story were in circulation by the Tang period; see Eoyang, "Wang Chao-chün Legend." Among the versions he lists, Michizane will have been aware of at least those 
frequently described as hearing the Qiang flutes; ${ }^{76}$ "drop[ping] a hairpin" (kamusashi o otosu 落釷) is a phrase used in at least one famous retelling of this story; 77 and Michizane's explicit reference to "sands" (isago 沙), which is here used to describe his sea voyage in a surprising metonymy, echoes the frequent reference to the deserts where Wang Zhaojun spent the remainder of her days. ${ }^{78}$ Murata suggests that this allusion, which is enabled through Michizane's double vision, served to increase the force of his expression of dismay over having to leave the capital like an unrecognized Wang Zhaojun. ${ }^{79}$ But I believe that this interpretation ignores an important aspect of the comparison, namely their ultimate incongruence: Michizane's unrequited compositional and textual ability are apparently of the same ilk as Wang Zhaojun's unemployed beauty, while governorship in the provinces is equated to marriage with a barbarian. ${ }^{80}$ Rather than a moment of deep pathos, the jukkai seems to have been employed to suggest a more humorous identification with a classical model, in a confusion that resembles the confusion of the two meanings - one ludic, one full of gravitas - of Ryūkaen. ${ }^{81}$ Thus if we take the Wang Zhaojun parallel seriously-and I think we should-it becomes very difficult to maintain the conventional interpretation of this poem. It was not a burst of uncontained grief, but a finely crafted banquet poem that simultaneously praised the occasion and the sovereign, lauded the double appropriateness of the dance, displayed the poet's

in Han Shu 漢書 (History of the Former Han), Hou Han Shu 後漢書 (History of the Later Han), and the poems by Bai Juyi.

76 Murata, "Michizane shishō," p. 34. The association was known to Heian poets: see for example Rabinovitch and Bradstock, Moonlight, pp. 168-69, 194-95.

77 Murata, "Michizane shishō," p. 40.

78 Ibid., p. 41. See Eoyang, "Wang Chao-chün Legend," p. 12. The danseuses' "painted beauty" (shifun 脂粉; "red and white make-up") may hint at Wang Zhaojun, in particular a version where she would not bribe the court painter to depict her more beautifully than she actually was (Murata, "Michizane shishō," pp. 41-42), or alternatively a variant in which Wang Zhaojun refused to use make-up herself. I am unsure if Michizane could have known this version (for which see Eoyang, "Wang Chao-chün Legend," pp. 6-7) but cosmetics are a motif in at least two other versions (lbid., pp. 11-12)

79 Murata, "Michizane shishō," pp. 42-43.

80 Bai Juyi, too, used Wang Zhaojun to allude to governorship ("Guo Zhaojun cun" 過昭君村; "Passing Through Zhaojun's Village, cited in Eoyang, "Wang Chao-chün Legend," pp. 13 and 22). This may suggest Zhaojun was a serious exemplum for those who departed from the capital.

81 For moments of humor in shi, see Rabinovitch and Bradstock, Moonlight, p. 38. erudition, and maybe even satirized his new appointment as the fate of a beautiful lady. ${ }^{82}$

The second passage commonly cited when reconstructing Michizane's departure for Sanuki is not actually part of a poem, but comes from the long headnote accompanying K184. Written in prose, it relates some of the events at the Naien banquet's concluding drinks and an interaction between Chancellor Mototsune and Michizane himself. The narrative, which is cited by almost every scholar who touches upon Michizane's appointment to Sanuki, ${ }^{8}$ is seen as an objective record of Michizane's role at the Naien banquet, and provides seemingly direct evidence of his devastation at being appointed governor. But even though the headnote did not have to negotiate the numerous expectations guiding poetic practice, I nevertheless doubt that we can simply read the passage as autobiographical narrative. ${ }^{84}$ First of all, such an interpretation relies on a very selective reading of Michizane's participation in the Naien banquet. It privileges evidence that meshes with preconceived ideas about the new governor's grief (viz. the headnote), and casts him as an emotional wreck, while virtually ignoring the fact that at that same banquet, Michizane was sufficiently compos mentis to compose the intricate (and equanimous) poem $\mathrm{K} 183 .{ }^{85} \mathrm{On} \mathrm{a}$

82 Haruna suggests ("Nin Sanuki no kami," p. 459) that the final line was not a cry of grief, pointing out that the verb tan 歎 can also mean "to eulogize," and reads the entire poem in that frame. I do not think we need to make such a clear-cut decision, and would rather choose to acknowledge the verb's ambiguity as a reflection of Michizane's own double vision.

83 A number of key points in the narrative are frequently cited: (a) attendance was an enormous honor (koto naru megumi nari 殊恩也); (b) Mototsune's solicitousness (Shōkoku, tsuide ni ataru o motte ... yō-zeshimu 相國以當次 ....詠); (c) Michizane choked up when he started reciting (oetsu su 嗚咽); and (d) a sleepless night (yomosugara neburazu 通夜不睡). See Borgen, Michizane, pp. 150-51 (who mentions points a, b, c, and d); Endō, "Sanshū jidai no Michizane," p. 101 (c); Endō, "Michizane no seiji," p. 2 (b, c); Fujiwara, Shijin no unmei, p. 155 (b); Haruna, "Nin Sanuki no kami," pp. 457-58 (c); Hatooka, Kyūtei shijin, p. 295 (b); Hirata, Kesareta seijika, pp. 55, 63-64 (a, b, c, d); lyanaga, "Ninna ninen no Naien," pp. 91-92 (a); Kawaguchi, NKBT 72, p. 31 (c); Kon, Sekkan seiji, p. 50 (b, c); Murata, "Michizane shishō," pp. 36-37 (a); Niboshi, "Bunjin no kokushi ninkan," p. 30 (a); Sakamoto, Michizane, p. 69 (c). lyanaga Teizō's interpretation ("Ninna ninen no Naien," p. 92) that Mototsune was harassing Michizane and waiting for him to drain the cup ignores the poem that this headnote accompanies and is a misjudgment of the relationship between the two men; see Haruna, "Nin Sanuki no kami," pp. 457-58.

84 Eoyang, "Generic Self," pp. 244-45.

85 This observation holds for the Sanuki poetry more generally: little attention has been paid to poems such as K191, a piece commemorating a successful rainmaking ritual, or K214, where 
textual level, too, this line of interpretation elides two important details about the headnote: its date of composition, and its function. As discussed, the headnote was likely composed well after the event, when Michizane compiled his poetry and intended to guide his readership's interpretation, possibly even in new directions. Not only did this color the narrative-through subsequent experiences in Sanuki, or nostalgia, for example-it also means that the author's aims with the poem may have radically changed since its original composition. Indeed, the fact that Michizane presented the poem to Daigo, towards whom a certain modicum of modesty was due, may serve to explain why Michizane emphasizes-overstates? - the special honor of his participation. ${ }^{86}$ In other words, even though a prose headnote is nowhere near as restricted in theme and diction as a poem, its contents are no historical document: their contents are conditioned by the audience and by the poem that had to be explained. Indeed, reading the headnote and the poem (K184) side by side makes it clear that many of the phrases in the former are no documentary record, but serve specifically to explicate expressions in the latter.

予爲外吏、幸侍内宴裝束之間、得預公宴者、雖 有舊例、又殊恩也。王公依次、行酒詩臣。相國以 當次、又不可辭盃。予前佇立不行。須眨吟曰、明 朝風景屬何人。一吟之後、命予高詠。蒙命欲詠、 心神迷亂、綥發一聲、涙流嗚咽。宴罷歸家、通夜 不睡。默然而止如病留塞。晑書左丞、在傍詳聞。 故寄一篇、以慰予情。

When I had become a provincial official, I was fortunate to serve at the Naien banquet while I was preparing for my voyage. To have the opportunity to participate in an official banquet under those circumstances - even if not without precedent-is still an exceptional favor.

Members of the royal family and the nobility, by order of their rank, all poured drinks for the poetic vassals. Because the chancellor's [Fujiwara no Mototsune] turn had come, he could not refuse the cup again. He stopped in front of me and

Michizane describes inviting some local officials to an informal, and apparently enjoyable, round of New Year's drinks.

86 Kido Yūko 木戸裕子 has shown how such self-deprecatory remarks became a staple of poetic prefaces, beginning in the late ninth century; Kido, "Heian shijo no keishiki," especially pp. 14-15. did not pour [me a cup]. ${ }^{87}$ After a brief pause, he spoke to me, reciting: “Tomorrow's landscape - to whom shall it belong?” After reciting it once, he instructed me to chant it out loud. I took up the order and wanted to chant, but my heart and mind were lost in confusion, and when I had barely uttered one sound, tears flowed and I broke into sobs.

After the banquet was over and I had returned home, all night I failed to get to sleep. Silent and unmoving, it was as if I was ill, and my chest felt tight. The Middle Controller of the Left [Fujiwara no Sukeyo] was nearby and listened to the full account. ${ }^{88}$ That is why I sent him one poem and thus consoled my feelings.

\section{自聞相國一開脣 \\ 何似風光有主人 \\ 忠信從來將竭力 \\ 文章不道獨當仁 \\ 含誠欲報承恩久 \\ 發詠無堪落淚頻 \\ 若出皇城思此事 \\ 定啼南海浪花春}

Since hearing the Chancellor parting his lips once [I have been wondering] why it resembles how "a scenery has a master."

Loyal and reliable, thus far I have been prepared to exhaust my strengths.
87 It is left implicit who the subject of "refuse the cup" (sakazuki o inamu 献盃) is; the various kakikudashi 書き下し (reading glosses) and translations (Kawaguchi, NKBT 72, p. 248; Hatooka, Kyūtei shijin, p. 295; Higashi, Kujira, pp. 74-75) shirk this interpretative difficulty. Perhaps banquet courtesy required Michizane to refuse the wine cup from higher nobles; but the fact that both tsuide 次 and choryū 佇立 refer to Mototsune suggests that it was the latter who could not refuse the cup. This would tally with the fact that he recited a poem, possibly instead of pouring Michizane a cup: I read 不行 as a call-back to sake o okonau 行酒 two sentences prior, glossing okonawazu instead of the common but pleonastic reading arikazu, "to stand still and not move" (Kawaguchi, NKBT 72, p. 248; Higashi, Kujira, p. 74).

88 Higashi, Kujira, p. 75, interprets the phrase to mean that Sukeyo was "well-informed about these matters" (kuwashii jijō o shitte iru〈わしい事情を知っている) instead. The anonymous reviewer makes the attractive suggestion that the phrase might refer not to Sukeyo's presence at Michizane's mansion, but at the banquet, which would render it "The Middle Controller of the Left had been by my side [at the Naien] and had heard everything in great detail." 
But as for my compositions, I do not say that I alone fulfil my responsibilities. ${ }^{89}$

With a feeling of sincerity in my heart, I want to return the favor, because I have long enjoyed your acts of kindness.

Beginning to chant, I am unable to contain myself, while my tears fall constantly.

If I would think of this event after I have left the capital,

I would certainly cry over [my appointment on] the Southern Sea - a spring on the spray of the breakers at Naniwa harbor..$^{90}$

In contrast to the headnote, which has attracted much attention and has been translated before, to my knowledge the poem has thus far not been translated, and the only scholarly treatment that I am aware of is the commentary in Kawaguchi's NKBT edition. Although my translation of this admittedly obscure poem is therefore of a very tentative nature, the headnote helps to clarify most (if not all) of the interpretative problems, starting from the poem's obscurity itself: we learn that it originally was a private exchange between Michizane and his friend Fujiwara no Sukeyo, to whom Michizane was grateful for his attention to the story about the banquet (tsubabiraka ni kikeri 詳聞). ${ }^{91}$ Sukeyo was also a close associate of Mototsune, suggesting that Michizane could have expected the poem to have been circulated to the chancellor as well..$^{92}$ The poem's audience was thus originally limited to those directly involved in the events it describes, and could therefore be terse and highly elliptic without risking reduction to obscurity.

To remedy the problem for the poem's potential new audience, the headnote fills in the details that initially had been silently understood in an exchange between familiars. Central among these details is the reading of the first two lines as an allusion to a line of poetry Mototsune had recited. This line, it turns out, is the final line of a poem Bai Juyi wrote for his friend Yuan Zhen

89 For the expression 當仁 (Ch. dang ren, Jp. jin ni ataru), see Lunyu 論語 15.36, consulted in Kaji, Rongo, p. 372

90 For another translation (headnote only), see Higashi, Kujira, pp. 74-75.

91 Or, in whom Michizane could confide because he had been present. See n. 88.

92 Higashi, Kujira, p. 75. The anonymous reviewer suggests, furthermore, that it may have been out of line for Michizane to write to Mototsune directly.
元穔 (779-831) as an expression of parting: at the time Bai and Yuan were both serving in the capital, and their separation (fensan qu 分散去 in the original) came as they set out for their respective offices at the break of dawn, each greeting a different scenery as they went. ${ }^{93}$ Although it seems likely that Mototsune's recitation was intended as encouragement, Michizane undermines this suggestion by questioning the appropriateness of the allusion - "Why does my situation resemble Bai Juyi's poem?":94 after all, Bai and Yuan had only been separated during the daytime, which is nothing like Michizane's four-year tour of duty.

The significance of 11. 3-4, unfortunately, is not entirely clear. In the translation, I have followed Kawaguchi's suggestion that Michizane means that he has exerted himself as a loyal subject but does not claim to be the only one whose responsibility lay in drafting exquisite compositions. These lines might thus refer to why he was invited despite the appointment: i.e., because of his compositional, bureaucratic skill set. ${ }^{95}$ By contrast, the headnote does provide much context for 11. 5-6; both headnote and couplet emphasize Michizane's original intention to comply with Mototsune's request. The headnote's formulation that "my heart and mind were lost in confusion" (kokoro tamashii madoimidarete 心神迷亂) during the banquet should be interpreted as a foil for the poem's "feeling of sincerity in my heart” (makoto o fufumite 含誠, 1. 5). ${ }^{96}$ Similarly, “a long time" (hisashi 舊, 1. 5) is relativized as an exaggeration for one night of sleeplessness (yomosugara nebu$r a z u$ 通夜不睡). That the headnote was constructed to contrast with the poem is suggested most clearly by 1.6 , which states that unlike at the banquet (where Michizane "barely uttered one sound," wazuka ni issei o hatsu suru nomi 纔發一聲; emphasis mine), after returning home Michizane could barely contain himself from repeating Mototsune's allusion ( yōo hatsu shite tauru koto $n a k u$ 發詠無堪; emphasis mine). ${ }^{97}$ Even Michizane's

93 See for example Kawaguchi, NKBT 72, p. 248. The poem in question is Baishi wenji 白氏文集, 14.0745.

94 This interpretation solves Kawaguchi's problem (NKBT 72, p. 248) on how to understand 似 (gotoshi).

95 Kawaguchi, NKBT 72, p. 681; Borgen, Michizane, p. 150.

96 The reading fufumu (modern fukumu) is used by Kawaguchi and is also listed in Nihon kokugo daijiten as an ancient variant reading for 含.

97 Haruna adds ("Nin Sanuki no kami," pp. 458-59) that II. 5-6 imply gratitude for Mototsune's encouragement rather than depression, and thinks that Michizane was overcome by emotion 
most mundane remark - that he was already preparing for departure (sōzoku no aida 裝束之間) ${ }^{98}$ as provincial official (geri 外吏) when he was invited to the banquet (Naien ni hamuberite 侍内宴) - serves to explain part of the poem, namely what "leaving the capital" (sumera miyako o idete 出皇城, 1. 7) and “this event" (kono koto 此事, 1. 7) refer to. ${ }^{99}$

The headnote thus provides, through contrast and explication, a key for reading the poem exchanged between Michizane and Sukeyo (and Mototsune?). It was originally composed in response to something that occurred at the banquet, and Michizane may well have been moved to tears by Mototsune's consoling words and felt a deep appreciation for Sukeyo's thoughtfulness. Indeed, the final line suggests that Michizane would rather spend the springtime with Sukeyo than at sea, suggesting a personal response to his appointment. Yet it is something altogether different to read Michizane's general despondency into a poetic commentary, which was written ex post facto and whose contents were dictated by a personal (but not autobiographical) poem that was itself written in partially exaggerated language and composed in response to a minor episode at a banquet where Michizane also wrote the successful composition found in K183. Indeed, as this convoluted logic indicates, the headnote is so far removed from whatever Michizane's authentic feelings about the governorship were that, even if he had been genuinely moved - for either gratitude or grief - it would be naive to take seemingly autobiographical facts at face value in a text so rhetorically overdetermined. Paratexts, in other words, are as opaque as the literary texts they accompany. ${ }^{100}$

The remaining three poems were all written at banquets, but in contrast to $\mathrm{K}_{183}$ these get-togethers were informal farewell gatherings in honor of Michizane himself, a fact reflected in the poetry, which is both shorter and less solemn than the Naien banquet composition intended for the sovereign's ears. Although

because the chancellor himself, at a public banquet, personally offered his cup to an official of only middle (fifth) rank.

98 For this interpretation, see Hirata, Kesareta seijika, p. 64, and see Kamata and Yoneyama, s.v. sōzoku 裝束 (4).

99 The rather late period of travel suggested by K188 implies that being called to the Naien banquet in the middle of preparations may be somewhat exaggerated as well, although as a poem written on the last day of spring, $\mathrm{K} 188$ too might be relying on a conventional trope (Higashi, Kujira, pp. 80-83).

100 See Steininger, "Manuscript Culture," esp. pp. 362-77. this no doubt granted the attending poets greater expressive bandwidth, they still worked within a particular set of boundaries. Some were explicit, such as the fact that all three poems were written after drawing rhyme words (tan'in), and needed to be appropriate for the social situation and the audience present, while others were less so. Crucial for understanding the next two poems (K185-K186), for instance, is the quatrain's implicit three-tier structure of statement-developmentpersonal response. The line that scholars quote from both $\mathrm{K} 185$ and $\mathrm{K} 186$ is only the first, expository, line of each poem.

\section{佾書左丞餞席、同賦贈以言、各分一字。〈探得時字。〉}

\section{讚州刺史自然悲 \\ \倍以言贈我時 \\ 贈我何言爲重寶 \\ 當言汝父昔吾師}

At a farewell banquet organized by Middle Controller of the Left [Fujiwara no Sukeyo], everyone composed on the theme "giving someone a [farewell] gift with words," and each person was given one [rhyme] character. (Drawing [a rhyme], I received the character "time, occasion" [時].)

As Governor of Sanuki Province, of course I am sad,

And the sadness multiplies on this occasion, when you give me a gift with your words.

As you give me your gift, which words become valuable treasures?

I shall tell you: "Your father was once my teacher."

相國東閤餞席。〈探得花字。〉

\section{爲吏爲儒報國家}

百身獨立一恩涯

欲辭東閤何爲恨

不見明春洛下花

At a farewell banquet at the Chancellor's [Fujiwara no Mototsune] Eastern Sidegate. (Drawing [a rhyme], I received the character "flower" [花].)

Serving as a provincial official, serving as a learned man, we repay the sovereign [of this land]: 

A hundred [different] people each stand on their own, yet [all are indebted because of] that same exceptional royal favor.
As I am about to leave the Eastern Sidegate be- hind, what causes these bitter feelings?
Not seeing, in the following spring, the flowers of the capital. ${ }^{101}$

The first line of $\mathrm{K} 185$ is cited as evidence that Michizane "did not hide his feelings of anguish" at his imminent departure. ${ }^{102}$ The first line of $\mathrm{K} 186$ is taken to mean that Michizane was beginning to come to terms with his appointment, ${ }^{103}$ although for this passage alone, a number of scholars are reluctant to take Michizane's poetry at face value, seeing it (apparently in line with their beliefs about Michizane's views of governorship) as a disingenuous attempt to save face. ${ }^{104}$ Unlike the opening of $\mathrm{K} 187$, however, where the poet is explicitly present (ware 我, see below), the first line of neither K185 nor K186 contains a (pro)noun that expresses the subject-either of "being sad" (kanashi 悲) or "serving as an official” (ri to nari 爲吏). ${ }^{105}$ And while the governor mentioned in $\mathrm{K}_{185}$ can only refer to Michizane himself, his sadness is portrayed as something more universal-something that occurs "of its own accord" (onozukara 自然). Because the function of the first line conventionally was to state the topic on or background against which the poem would be developed, it is much more natural to take these lines not as expressions of personal sentiment but as a point of view that is shared between the banquet's participants.

This is, in fact, also suggested by the language of both poems. In the first, because the sadness occurs "of its own accord"-i.e. independent of the "I," the language use draws our attention away from the poet himself and opens up the possibility to develop the poem in

101 For alternative translations of K185, see Kawaguchi, NKBT 72, p. 249, and Rabinovitch \& Bradstock, Butterflies, p. 129. For alternative translations of K186, see Borgen, Michizane, p. 157; Endō, "Sanshū jidai no Michizane," p. 102; Higashi, Kujira, p. 76; Kawaguchi, NKBT 72, p. 249; and Rabinovitch \& Bradstock, Butterflies, p. 130.

102 Hatooka, Kyūtei shijin, pp. 231, 296. See also Haruna, "Nin Sanuki no kami," p. 456.

103 Borgen, Michizane, p. 157; Endō, "Michizane no seiji," p. 4; Hatooka, Kyūtei shijin, p. 295 (but hesitantly); Kon, Sekkan seiji, pp. 62-63; Sakamoto, Michizane, p. 70.

104 Hatooka, Kyūtei shijin, p. 230; Rabinovitch and Bradstock, Butterflies, p. 130; Sakamoto, Michizane, p. 70.

105 See Eoyang, "Generic Self," pp. 248-50. a different direction. It was written under the theme of "sending people off with words," a learned allusion to a meeting between Confucius 孔子 and Laozi 老子 told in the Record of the Grand Historian (Shiji 史記). ${ }^{106}$ From the second line, Michizane moves away from the theme of the governorship and begins steering in Sukeyo's direction: what really moves him, Michizane claims, is not so much the appointment, but the fact that Sukeyo mentioned his former mentor, Michizane's father Sugawara no Koreyoshi 菅原是善 (812-880). The poem apparently replies to something Sukeyo, the host of the banquet, had said before, and is formulated in such a way that it emphasizes, in the rhetorically prominent final line, the personal relationship between the two men. ${ }^{107}$ The governorship, by contrast, functions only as a foil to bring Michizane's appreciation for his friend into higher relief. In other words, instead of glossing the poem as "I feel terrible about Sanuki, and now it gets even more terrible," I would argue that, given the poem's structure and the fact that it addresses the banquet's host, we should rather read it as "Of course, what you say about governorships is true-but I am moved far more because you express your feelings of indebtedness to my late father." The poem was not written to be about the mission to Sanuki, but composed to lament the separation from Sukeyo.

The same applies, grosso modo, to the next poem. "Serving as an official, serving as a learned man" does not reflect Michizane's personal resolution to "repay the sovereign," ${ }_{108}$ but instead describes what all officials do in return for the "exceptional royal favor" (i.e., being selected to serve in the court bureaucracy). ${ }^{109}$ That

106 Shiji, "House of Confucius" section (Kongzi shijia, 6). This passage describes how a young Confucius, taking his leave after a meeting with Laozi, remarked, "I have heard that the rich give someone a send-off with treasures, while the humane give someone a send-off with words. I am unable to do as the rich, so I will appropriate the title of a humane person, and send you off, Master, with words" (吾聞富貴者送人以財,仁人者送人以言。吾不能 富貴,盤仁人之號, 送子以言). See Kawaguchi, NKBT 72, p. 249.

107 See Endō, "Sanshū jidai no Michizane," p. 102.

108 Most commentators and translators interpret kokka as "nation" or "state," but this seems anachronistic. As Kokushi daijiten explains (s.v. kokka), the term referred to the sovereign and his entourage in ancient sources. The use of kokka as a term for institutions of government is a medieval development, with the meaning coming to include land area and subjects only as late as the early modern period. Kokka as "sovereign" meshes well with a parallel in K484.177, which suggests that the kokka is the one to whom one owes a debt of gratitude. For ongai 恩涯, see Hatooka, Kyūtei shijin, p. 139

109 For the contrast, see also K324. 
the first line is again not to be interpreted as having a first-person subject is suggested by the following line's “hundred persons" (hyakushin 百身, 1. 2), which probably refers to the "hundred different officials" (hyakkan 百官) at court. ${ }^{110}$ Granted, this opening creates a particular expectation with the audience about how Michizane might react to being reassigned from a position as learned man at the Bureau for Higher Learning to become a provincial official. But this expectation remains unfulfilled when in the third line, Michizane shifts his attention to his participation in Mototsune's poetry banquets at the Eastern Sidegate and praises the blossoms in the capital. Michizane is reminded of these flowers as he leaves the Eastern Sidegate, and they therefore represent more than just a vague metaphor for life in the capital. ${ }^{111}$ We should recall that Michizane drew "flower" as his rhyme-word, whose use in this poem is therefore not just a reference to flower-viewing in general but symbolizes the playful versification that took place at Mototsune's mansion-indeed, we may surmise that flowers were often the poetic topic at the Eastern Sidegate sessions. The rhetoric is thus one of deference to the host, similar to that of K185: "You may think that I feel bitter because I have to leave behind my old post at the bureau, but actually it is because I can no longer join your blossom viewing parties." The poem was not written to display Michizane's sense of duty, but composed to convey a sense of gratitude to Mototsune, master of the banquet.

At banquets organized especially for him, Michizane made the understandable choice to praise his host in elaborate terms. In the final poem, written at a banquet at the Bureau for Higher Learning, there is no explicit host, but audience and situation nevertheless determined how Michizane expressed himself. Unlike at Mototsune's farewell banquet, where he poetically staged the learned man ( $j u$ 儒) and the provincial official ( $r i$ 吏) side by side, here Michizane found himself in the company of scholars, as is reflected in the antithesis Michizane sketches in the final of the five poems (K187).

\footnotetext{
110 Higashi, Kujira, p. 76. This line is often read in the first person: see Endō, "Sanshū jidai no Michizane," p. 102 (who speaks of Michizane's kakugo 覚悟 or "resolve"); Kawaguchi, NKBT 72, p. 249; and Rabinovitch and Bradstock, Butterflies, p. 130. 111 Hatooka, Kyūtei shijin, p. 268.
}

北堂餞宴、各分一字。〈探得遷。〉

\section{我將南海飽風煙 \\ 更妬他人道左遷 \\ 倩憶分憂非祖業 \\ 徘䧃孔聖廟門前}

At a farewell banquet in the Northern Hall [at the Bureau for Higher Learning], one character was distributed to everyone. (Drawing [a rhyme], I received "change, departure" [遷].)

I will surely, on the Southern Sea, grow sick of [the scenery of] wind and mist.

What's even more upsetting is how others speak of my "demotion."

I have carefully considered it, but "sharing the ruler's grief" was not the task of my forefathers.

I walk to and fro in front of the gate to the Temple of the Sage Confucius. ${ }^{112}$

Compared to K185-K186, Michizane is much more vocal about his appointment. The first-person ware 我 as the explicit subject of "growing sick of the wind and mist” (akidaru 飽, 1. 1) makes it clear that the poem represents his own expectations about how the provincial governorship will come to affect him in the years of service to come. ${ }^{113}$ This sense of apprehension is not negated, as it was in $\mathrm{K}_{185}-\mathrm{K} 186$, but developed more intensely throughout the poem. In 1. 2, Michizane replaces his future fears with a complaint about current rumors surrounding his reappointment. In 1. 3, "sharing the ruler's grief” (bun'yū 分憂) - a common trope for governorship ${ }^{114}$ - is seemingly rejected in favor of Michizane's ancestral occupation, i.e. the scholarly activities at the bureau that his father Koreyoshi (whom Sukeyo had remembered as his teacher) and grandfather Kiyokimi 清公 (alternatively, Kiyotada/Kiyotomo, 770-842) fulfilled before him. In 1. 4, Michizane is loath to leave the bureau's Confucius temple where,

\footnotetext{
112 For other translations, see Endō, "Sanshū jidai no Michizane," p. 103; Hatooka, Kyūtei shijin, p. 130; Higashi, Kujira, p. 77; Rabinovitch \& Bradstock, Butterflies, pp. 130-31.

113 As Higashi remarks (Kujira, pp. 77-79), the expression "wind and mist" (fūen 風煙) is an expression Bai Juyi used in his provincial poetry to describe the allure of the countryside, suggesting again Michizane's navigation of literary expectation as much as of personal sentiment.

114 Kawaguchi, NKBT 72, pp. 249-50.
} 
as Hatooka points out, the sekiten 釋奠 memorial rites for the sage would be held in less than a month, and which he would be unable to attend this year. ${ }^{115}$ Before concluding that this poem is a personal piece providing us with autobiographical detail, however, it is worth considering if, given the setting of the banquet, the poet could have expressed himself otherwise. When interpreting 1.3 we should keep in mind that the banquet was held at the bureau: if there is any place where Michizane should speak of his scholarly family tradition it would have been here, and either bragging about his new appointment-we could also read 1. 3 as an expression of suppressed pride at being the first in his family to attain this new status - or claiming to be happy to leave the bureau behind would have been nothing less than an insult to his colleagues and students. In fact, we know that Michizane is twisting the facts in order to emphasize his connection to the bureau, for as Robert Borgen and Takenaka Yasuhiko (among others) have pointed out, both Michizane's grandfather and uncle had served as governors in loco. ${ }^{116}$ Michizane selectively forgets this part of his family history because in the company of his colleagues and fellow scholars it would have been a faux pas to exclaim, "So long, and thanks for all of this!"

Significantly, this is the poem that, because of its explicit mention of the word "demotion" (sasen), has been a cornerstone in the debate on how to evaluate Michizane's appointment. ${ }^{17}$ Even though the poem only goes so far as to say that this was a rumor going around, many have seen it as evidence that Michizane himself did consider his appointment an insult tantamount to exile. ${ }^{118}$ But as the headnote shows, the reason the line ends in sasen is to accommodate the character Michi-

115 Hatooka, Kyūtei shijin, pp. 124, 129, 296. For a brief evaluation of Michizane's attitude toward the sekiten, see McMullen, Worship of Confucius in Japan, pp. 94-98.

116 This contrasts with yōnin 遥任 governors, who remained in the capital. See Borgen, Michizane, p. 152; Takenaka, "Sanuki no kami Michizane," p. 278.

117 Borgen, Michizane, p. 152; Endō, "Michizane no seiji," p. 4; Fujiwara, Shijin no unmei, pp. 111-12; Haruna, "Nin Sanuki no kami," pp. 455-59; Hatooka, Kyūtei shijin, pp. 124, 129, 231; Higashi, Kujira, pp. 76-77; Kon, Sekkan seiji, pp. 46-47; Niboshi, "Bunjin no kokushi ninkan," pp. 28-29; Rabinovitch and Bradstock, Butterflies, pp. 130-31; Sakamoto, Michizane, p. 70.

118 Hirata, Kesareta seijika, p. 55; Fujiwara, Shijin no unmei, pp. 112-13; Hatooka, Kyūtei shijin, p. 299; Rabinovitch and Bradstock, Butterflies, p. 130; Takenaka, "Sanuki no kami Michizane," p. 281 Niboshi urges us ("Bunjin no kokushi ninkan," p. 37) to remember how different parties at court would have held different interpretations of the appointment. zane had drawn for his composition: sen 遷, “change places," a word that by itself carries strong associations with demotion and exile. ${ }^{119}$ As already briefly touched upon above, exile was one of the main tropes late ninth-century poet-scholars used to talk about their provincial appointments, ${ }^{120}$ so one could readily interpret this line as the author's acknowledgement of the community that shared this language: not just bureau graduates in general, as Niboshi Jun has suggested, ${ }^{121}$ but the specific audience present for this banquet that imagined governorship as demotion. If (as Reeves has proposed) the rhymes were not always truly random, I would expect that Rabinovitch and Bradstock are right to suggest that the appearance of this somewhat uncommon character was not "an awkward coincidence." Instead, we should imagine that someone involved in the organization of the banquet had decided to include this rhyme so as to hint at sasen, banter that Michizane acknowledged in his poem: "This is a dirty trick you played on me, including this rhyme and implying that my assignment is actually a demotion!" In other words, we might read the line to imply that Michizane took the bait, and replied to what it insinuated to such people as were present at a bureau banquet. As with the other banquet poems analyzed above, Michizane did not just unabashedly write how he felt. He was compelled to comply with the rules of the game-actual rules, such as the tan' in rhyme, as well as unwritten social expectations that determined how he could represent himself and his family tradition.

In this section, I have explored how rhetorical, poetic, generic, and social conventions helped shape Michizane's predeparture poetry, and how reading strategies informed by these conventions complicate an autobiographical reading of these poems. Given the results of this exploration, the idea that Michizane wrote these poems primarily as personal intimations is in my view untenable, which implies a need to reconsider the historical narrative of Michizane's governorship as a bleak period in his life. As such, these results also give cause for scepticism regarding other moments in

119 See the definitions in Kamata and Yoneyama, Shin kangorin, s.v. 120 Niboshi, "Bunjin no kokushi ninkan," pp. 30-31.

121 lbid., p. 37.

122 Rabinovitch and Bradstock, Butterflies, pp. 130-31. The character 遷 (rhyme category 先) is one in a large pool of potential rhymes, further suggesting this one appeared by design. In the remainder of Michizane's poetic oeuvre, as a rhyme it is only used once, in $\mathrm{K}_{4} \mathrm{O} 2$, where it is used in its neutral sense "to move." 
his biography that heavily rely on the poems as source material, and suggest that there is considerable room for new discoveries about how shi were used as an instrument for the negotiation of hierarchies and social expectations, both by Michizane and by Heian shi poets in general.

\section{Conclusion}

In the first section of this article, I argued that scholars' constructions of Michizane's personal voice can be explained through at least two modern developments: the creation of the loyal Japanese poet-hero Michizane and the entrenchment of literature as a medium of personal expression. Both have contributed to the notion that Michizane's poetry should be read as autobiographical portrayals of Michizane's inner life, but as I showed in section two, recent scholarship on Heian shi practice suggests that such a reading strategy should be problematized. It flags a variety of external factors that poets needed to negotiate during the composition of these poems, including genre expectations, rhetorical structures, situation, and audience. In an attempt to accommodate these factors, in section three I offered alternative interpretations of the five Sanuki poems Michizane wrote before his departure. In this experiment, I have constantly distanced myself from the question of what their personal language can tell us about Michizane's subjective experience of his governorship, and instead tried to explain how the use of such language may be understood in terms of the poetics of shi.

The possibility of such an interpretation complicates the received autobiographical reading, on which questions about Michizane's governorship rely: questions that, as I have argued in the introduction, seem to require an answer because of their shared assumption that the governorship was a setback. Suppose instead, as I have done, that Michizane's poetry was not written as autobiography; that his use of such language was instead motivated by poetic practice; and that we therefore have no reason to assume that Michizane was disappointed with the assignment: from this perspective, the questions that have occupied historians and biographers - "Why was Michizane demoted?" and "Why was Michizane upset?" - are much less elucidating than an investigation of the dual rhetorics of grief and exile: "How did Michizane employ these tropes?"
"What could he hope to achieve by the use of such language?" Such close reading strategies for Michizane's poetry (and by extension, for other shi poets as well) may give the impression that I intend to categorically deny that Michizane harbored negative personal feelings about the Sanuki governorship. But whether or not he did feel that way is not the point. Rather, I have shown that whenever the poet says "I" - and on many occasions when he does not-we should be cautious to read these as moments of autobiographical expression that can be explained in terms of individual self. There are many possible reasons to talk about "I" besides the desire to give vent to lyrical passions.

Attention to the rhetorical instead of the expressive nature of poetic language opens up new avenues of research into the oeuvre of Michizane and other poets, not only of shi but also uta 歌/waka-Ariwara no Narihira 在原業平 (825-880), a contemporary of Michizane's father, and Ono no Komachi 小野小町 (mid-ninth century BCE) being only two examples that come to mind of poets whose biographies heavily rely on their presumed literary oeuvre. ${ }^{123}$ Concerning Michizane, one could think for example of the poetry he exchanged with his tutor-cum-father-in-law Shimada no Tadaomi 島田忠臣 (828-891), and the social functions this may have fulfilled in addition to purely private ones. ${ }^{124}$ Alternatively, the poems that discuss backbiting at the bureau and rumors that Michizane wrote diatribes against high court officials may be read as more than personal frustration at the pettiness of court society, ${ }^{125}$ serving instead as persuasory compositions intended for circulation, whose language was enhanced through silence, understatement, or hyperbole for political effect.

Equally tantalizing is the potential of such strategies in interpreting Michizane's use of poetry in the context of his actual exile to Dazaifu. Given how Wiebke Denecke, in her book Classical World Literatures: SinoJapanese and Greco-Roman Comparisons, has signalled an "emotional realism projected onto the exile poetry" of Michizane's one-fascicle collection of exile poems Kanke kōshū 菅家後集 (The Later Sugawara Collec-

\footnotetext{
123 The constructedness of Komachi's life has been the explicit subject of investigation in Terry Kawashima's Writing Margins, pp. 124-29.

124 This topic has already been the subject of a first exploration in Reeves, "Poetry, Patronage, and Politics," chapter 4 (pp. 477-599). 125 Borgen, Michizane, pp. 133-40.
} 
tion $)^{126}$ it may prove very valuable to reread this work from a non-autobiographical perspective. In addition, I would argue the original Kanke bunso should also be considered in this regard. The reason behind the compilation and presentation to the throne are not entirely clear: Michizane himself only vaguely explains that he followed the advice of "[s]ome vassal" who "recommended to me to present some of my literary drafts to the throne" (jishin aru hito shin o susumete, bunsō no tashōo tatematsurashimu 侍臣或人勸臣、令獻文草 多少). ${ }^{127}$ It has been suggested that such enterprises represented "the symbolic relationship that royal involvement with poetry projects in Sino-Japanese sought to express," 128 but such relationships affirmed not only the role of the sovereign, but also of the poets who undertook those projects. Although Michizane is not explicit about the function Kanke bunso was expected to fulfil, one might for example suggest that its presentation was intended as an act of self-justification.

In this regard, it is significant that Michizane presented the collection to Daigo tennō in the autumn of 900, a mere five months before his exile. Although we should be wary of teleological misrepresentation, we do know that Michizane had received a letter from Miyoshi no Kiyoyuki, a courtier who had divined catastrophe for Michizane in the year 901, and who warned him to "know where to stop" (sono shisoku o shiru 知其 止足). ${ }^{129}$ Michizane was not on good terms with him, and might have dismissed this as relatively harmless political slander, but three petitions Michizane submitted to the throne to plead to be dismissed as Minister of the Right (udaijin 右大臣; see K629-K631) suggest Michizane's own uncertainty about his standing at court. Could it be possible that the presentation of Kanke bunsō was also part of a strategy to secure his reputation? Such a reading seems attractive, for it would help explain the existence of Kanke bunsō's "other" half: the six fascicles of prose, which have thus far received very little attention because of their apparently low literary value. We might read poetry and prose together to suggest the persona of a loyal scholar who has served through several reigns through study, service, and the composition of poetry and prose as the sovereign

\footnotetext{
126 Denecke, Classical World Literatures, p. 232.

127 Kawaguchi, NKBT 72, p. 618.

128 Smits, "Sorting out Songs," p. 15.

129 Honchō monzui 本朝文粹 7.187. See Hérail, Miyoshi no Kiyoyuki, pp. 36-39; 231-33
}

commanded - who acted, in other words, in accordance with the Confucian ideal of the scholar-minister, and did not deserve to be punished.

We cannot be certain, of course, that Michizane already anticipated that he would fall as deep as he did. But if he did expect some form of retribution from his political rivals, then a more permanent sojourn in the province was not inconceivable. Personally, I doubt that the Sanuki governorship was the troubled period so many scholars have made it out to be. But their interpretation is more than a mere mirage. Fifteen years later, on the eve of exile, Michizane selected precisely these poems to stand at the beginning of the two fascicles of Sanuki poetry. Here, couched in the suggestive language of headnotes and placed in mutually reinforcing coordination, their personal, emotional language created a new narrative of the Sanuki period for a new audience, a narrative of hardship that might convince Michizane's rivals to take pity on him and forgo condemnation to a new, undeserved journey into exile. But that was in 9oo. When he joined the banquets in 886 , on the eve of an unexpected-but not necessarily unwanted-appointment, not even Michizane knew then what emotions and experiences his time in the province would have in store for him.

\section{Reference List}

\section{- Abbreviation Used}

NKBT Nihon koten bungaku taikei 日本古典文学大系. 102 vols. Iwanami Shoten, 1957- 1967.

\section{- Sources}

Batten, Bruce. "Provincial Administration in Early Japan: From Ritsuryō kokka to Ōchō kokka." HJAS 53:1 (1993), pp. 103-34.

Borgen, Robert. Sugawara no Michizane and the Early Heian Court. Council on East Asian Studies, Harvard University, 1986.

Brownstein, Michael C. "From Kokugaku to Kokubungaku: Canon-Formation in the Meiji Period.” HJAS 47:2 (1987), pp. 435-6o.

Denecke, Wiebke. Classical World Literatures: Sino-Japanese and Greco-Roman Comparisons. Oxford University Press, 2014. 
Endō Mitsumasa 遠藤光正. “Sanshū jidai no Sugawara no Michizane to Kansō jūshu” 讃州時代の菅原道真と「寒 早十首」. Tōyō kenkyū 東洋研究 113 (1994), pp. 99-128.

Endō Mitsumasa. "Sanuki no kami Sugawara no Michizane no seiji to sono shibun” 讃岐守菅原道真の政治とその 詩文. Tōyō kenkyū 143 (2002), pp. 1-32.

Eoyang, Eugene. “The Generic Self: Anecdotal vs. Autobiographical References to Personal History." Canadian Review of Comparative Literature / Revue Canadienne de Littérature Comparée 39:3 (2012), pp. 244-56.

Eoyang, Eugene. "The Wang Chao-chün Legend: Configurations of the Classic." Chinese Literature: Essays, Articles, Reviews 4 (1982), pp. 3-22.

Fujiwara Katsumi 藤原克己. “Sugawara no Michizane: Le poète." Cipango, Cahiers d'études japonaises 13 (2006), pp. 135-63.

Fujiwara Katsumi. Sugawara no Michizane: Shijin no unmei 菅原道真: 詩人の運命. Wedge, 2002.

Fujiwara Katsumi. Sugawara no Michizane to Heianchō kanbungaku 菅原道真と平安朝漢文学. Tokyo University Press, 2001.

Gerlini, Edoardo, ed. Sugawara no Michizane: Poesie scelte. Rome: Aracne, 2013.

Haruna Hiroaki 春名宏昭. “Sugawara no Michizane no nin Sanuki no kami” 菅原道真の任讃岐守. In Sugawara no Michizane ronshū 菅原道真論集, ed. Wakan Hikaku Bungakukai 和漢比較文学会, pp. 448-70. Bensei Shuppan, 2003.

Hatooka Akira 波戸岡旭. Kyūtei shijin Sugawara no Michizane: Kanke bunsō, Kanke kōshū no sekai 宮廷詩 人菅原道真:『菅家文草』『菅家後集』の世界. Kasama Shoin, 2005

Heldt, Gustav. The Pursuit of Harmony: Poetry and Power in Early Heian Japan. East Asia Program, Cornell University, 2008.

Hérail, Francine. "De la place et du rôle des gouverneurs de province à l'apogée de l'époque de Heian.” Autour du Genji monogatari (Cipango, Hors-série 2008), pp. 291-355.

Hérail, Francine. Un fonctionnaire lettré: Miyoshi no Kiyoyuki (847-918) en son temps. Paris: Collège de France, Institut des Hautes Études Japonaises, 2016.

Higashi Shigemi 東茂美. Kujira to yobareta otoko: Sugawara no Michizane 鯨鯢と呼ばれた男: 菅原道真. Fukuoka: Kaichōsha, 2019.

Hirata Kōji 平田耿二. Kesareta seijika Sugawara no Michizane 消された政治家菅原道真. Bungei Shunjū, 2000
Ijiri Kazuo 井尻千男. “Metafijikaru historī: Daigo-tei to sono jidai (dai sanshō) Michizane higeki no shinsō” メ夕フ イジカル・ヒストリー: 醍醐帝とその時代 (第3章) 道真悲劇 の真相. Shin Nihongaku 新日本学 22 (2011), pp. 120-32.

Ikeda Kikan 池田龜鑑, ed. Makura no sōshi 枕草子. In NKBT 19.

Iyanaga Teizō 彌永貞三. “Ninna ninen no Naien” 仁和二年 の内宴. In Nihon kodaishi ronshū 日本古代史論集, vol. 2, ed. Sakamoto Tarō Hakase Kanreki Kinenkai 坂本太 郎博士還暦記念会, pp. 503-64. Yoshikawa Kōbunkan, 1962. (Reprinted in Iyanaga Teizō, Nihon kodai no seiji to shiryō 日本古代の政治と史料, pp. 41-98. Takashina Shoten, 1988.)

Kaji Nobuyuki 加地伸行, ed. Rongo: Zōhoban 論語: 増補版. Kōdansha, 2009.

Kamata Tadashi 鎌田正 and Yoneyama Toratarō 米山寅太郎. Shin kangorin 新漢語林. Taishūkan, 2004.

Kawaguchi Hisao 川口久雄, ed. Kanke bunsō, Kanke kōshū 菅家文草·菅家後集. NKBT 72.

Kawaguchi Hisao and Wakabayashi Tsutomu 若林力. Kanke bunsō, Kanke kōshū shiku sō-sakuin『菅家文草』・『菅家 後集』詩句総索引. Meiji Shoin, 1978.

Kawashima, Terry. Writing Margins: The Textual Construction of Gender in Heian and Kamakura Japan. Harvard University Asia Center, 2001.

Kido Yūko 木戸裕子. "Heian shijo no keishiki: Jikenku no kakuritsu o chūshin toshite” 平安詩序の形式: 自謙句の 確立を中心として. Gobun kenkyū 語文研究 69 (1990), pp. $12-24$.

Kodama Kōta 児玉幸多, ed. Kuzushiji yōrei jiten: Fukyūban くずし字用例辞典: 普及版. Tōkyōdō, 1981.

Kokushi daijiten 国史大辞典. https://japanknowledge.com /library/en/

Kon Masahide 今正秀. Sekkan seiji to Sugawara no Michizane 摂関政治と菅原道真. Yoshikawa Kōbunkan, 2013.

Kornicki, Peter F. "A Note on Sino-Japanese: A Question of Terminology." Sino-Japanese Studies 17 (2010), pp. 29-44.

Kurozumi, Makoto, and David Lurie, trans. "Kangaku: Writing and Institutional Authority." In Inventing the Classics: Modernity, National Identity, and Japanese Literature, ed. Haruo Shirane and Tomi Suzuki, pp. 201-19. Stanford University Press, 2000.

LaMarre, Thomas. Uncovering Heian Japan: An Archaeology of Sensation and Inscription. Duke University Press, 2000.

Matsuda, William. "Poets on the Periphery: Kūkai's Vision of Frontier Governance." Journal of Asian Humanities at Kyushu University 4 (2019), pp. 21-37. 
McMullen, James. The Worship of Confucius in Japan. Harvard University Asia Center, 2020.

Murata Masahiro 村田正博. “Michizane shishō: Sōshun Naien ni shite Ryūkaen no kyoku o kiku (Kanke bunsō kan san - 183)" 道真詩抄: 早春内宴にして柳花怨の曲を 聴〈(菅家文草巻三-一八三). Jinbun kenkyū 人文研究 44:13 (1992), pp. 31-45.

Niboshi Jun 二星潤. “Kyūseiki ni okeru bunjin no kokushi ninkan: Sugawara no Michizane no Sanuki no kami ninkan o tegakari ni” 九世紀における文人の国司任官: 菅原道真の讃岐守任官を手がかりに. Historia: Journal of Osaka Historical Association ヒストリア 267 (2018), pp. 28-47.

Nihon kokugo daijiten 日本国語大辞典. https://japanknowledge.com/

Ogawa Tamaki 小川環樹. Tōshi gaisetsu 唐詩概説. Iwanami Shoten, 2005.

Ōoka Makoto 大岡信 and Akiyama Ken 秋山虔. “'Taidan’: Shi no shisō, shi no hihyō; Sugawara no Michizane to Ki no Tsurayuki” [対談]: 詩の思想·詩の批評; 菅原道真 と紀貫之. Kokubungaku: Kaishaku to kyōzai no kenkȳu 國文學: 解釈と教材の研究 37:12 (1992), pp. 6-26.

Piggott, Joan R. The Emergence of Japanese Kingship. Stanford University Press, 1997.

Poch, Daniel. "Measuring Feeling as Theory of Literature: Romanticism and the Performance of Genre in Natsume Sōseki's Kusamakura and Critical Writings.” MN 73:1 (2018), pp. 1-26.

Rabinovitch, Judith N., and Timothy R. Bradstock. Dance of the Butterflies: Chinese Poetry from the Japanese Court Tradition. East Asia Program, Cornell University, 2005.

Rabinovitch, Judith N., and Timothy R. Bradstock. No Moonlight in My Cup: Sinitic Poetry (Kanshi) from the Japanese Court, Eighth to the Twelfth Centuries. Leiden: Brill, 2019.

Reeves, Kristopher. "Of Poetry, Patronage, and Politics: From Saga to Michizane, Sinitic Poetry in the Early Heian Court." PhD dissertation, Columbia University, 2018.

Sakaki, Atsuko. Obsessions with the Sino-Japanese Polarity in Japanese Literature. University of Hawai'i Press, 2006.

Sakamoto Tarō 坂本太郎. Sugawara no Michizane 菅原道真. Yoshikawa Kōbunkan, 1962.

Sasaki Keisuke 佐々木恵介. Zuryō to chihō shakai 受領と 地方社会. Yamakawa Shuppansha, 2004.

Shiji 史記. “House of Confucius” 孔子世家. https://ctext .org/shiji/kong-zi-shi-jia

Shirane, Haruo. "Curriculum and Competing Canons." In Inventing the Classics: Modernity, National Identity, and
Japanese Literature, ed. Haruo Shirane and Tomi Suzuki, pp. 220-49. Stanford University Press, 2000.

Shirane, Haruo. "Introduction: Issues in Canon Formation." In Inventing the Classics: Modernity, National Identity, and Japanese Literature, ed. Haruo Shirane and Tomi Suzuki, pp. 1-27. Stanford University Press, 2000.

Shirane, Haruo, ed. Traditional Japanese Literature: An Anthology, Beginnings to 1600. Columbia University Press, 2007.

Smits, Ivo. "Sorting Out Songs: Reconsidering the Classics of Heian Court Culture." PMJS Papers, July 2015. www.pmjs .org/pmjs-papers/papers-index/smits-sorting.

Smits, Ivo. "The Way of the Literati: Chinese Learning and Literary Practice in Mid-Heian Japan.” In Heian Japan, Centers and Peripheries, ed. Mikael S. Adolphson, Edward Kamens, and Stacie Matsumoto, pp. 105-28. University of Hawaici Press, 2007.

Steininger, Brian. Chinese Literary Forms in Heian Japan: Poetics and Practice. Harvard University Asia Center, 2017.

Steininger, Brian. "Manuscript Culture and Chinese Learning in Medieval Kamakura." HJAS 78:2 (2018), pp. 339-69.

Stockdale, Jonathan. Imagining Exile in Heian Japan: Banishment in Law, Literature, and Cult. University of Hawaici Press, 2015.

Sugawara no Michizane 菅原道眞. Kanke bunsō 菅家文草. Dōmyōji Tenmangū 道明寺天満宮 manuscript. https:// kotenseki.nijl.ac.jp/biblio/100292484/viewer.

Sugawara no Michizane. Kanke bunsō. Hizen Shimabara Matsudaira Bunko 肥前島原松平文庫 manuscript. https://kotenseki.nijl.ac.jp/biblio/100223166/viewer.

Sugawara no Michizane. Kanke bunsō. Genroku 元禄 13 (1700) print edition. https://dl.ndl.go.jp/info:ndljp /pid/256289o.

Sumiyoshi Tomohiko 住吉朋彦. “Gozanban no sōtei” 五山版 の装訂. Ritsumeikan bungaku 立命館文學 664 (2019), pp. 472-89.

Takenaka Yasuhiko 竹中康彦. "Sanuki no kami Sugawara no Michizane ni kan-suru ichi kōsatsu” 讃岐守菅原道真 に関する一考察. In Kodai chūsei no shakai to kokka 古代中世の社会と国家, ed. Ōsaka Daigaku Bungakubu Nihonshi Kenkyūshitsu 大阪大学文学部日本史研究室, pp. 267-84. Seibundō, 1998.

Taniguchi Kōsuke 谷口孝介. Sugawara no Michizane no shi to gakumon 菅原道真の詩と学問. Hanawa Shobō, 2006.

Tokoro Isao 所功. Sugawara no Michizane no jitsuzō 菅原道真 の実像. Rinsen Shoten, 2002. 
Tuck, Robert. Idly Scribbling Rhymers: Poetry, Print, and Community in Nineteenth-Century Japan. Columbia University Press, 2018.

Tuck, Robert. "Poets, Paragons, and Literary Politics: Sugawara no Michizane in Imperial Japan." HJAS 74:1 (2014), pp. 43-99.

Watanabe Minoru 渡辺実. Makura no sōshi. Vol. 25 of Shin Nihon koten bungaku taikei 新日本古典文学大系. Iwanami Shoten, 1991.

Watson, Burton. Japanese Literature in Chinese. Vol. I: Poetry \& Prose in Chinese by Japanese Writers of the Early Period. Columbia University Press, 1975.

Webb, Jason P. "In Good Order: Poetry, Reception, and Authority in the Nara and Early Heian Courts." PhD dissertation, Princeton University, 2004.

Winslow, Donald J. "Glossary of Terms in Life-Writing, Part I.” Biography 1:1 (1978), pp. 61-78.

Wixted, John Timothy. "Kanbun, Histories of Japanese Literature, and Japanologists." Sino-Japanese Studies 10:2 (1998), pp. 23-31.

Yoda, Tomiko. Gender and National Literature: Heian Texts in the Construction of Japanese Modernity. Duke University Press, 2004. 